\title{
Analysis Interaction Patterns of People In Dongi-Dongi Towards The Management Of Forest Resources
}

\author{
Sitti Aminah ${ }^{1}$, A Muis $^{2}$, Livawanti $^{3}$, Rafiuddin $^{4}$, R Gailea $^{5}$ \\ \{sittiaminah76@gmail.com ${ }^{1}$ ) \\ Faculty of Agriculture, Universitas Muhammadiyah Palu, 94118 Indonesia ${ }^{1,3,4,5}$, Faculty of \\ Agriculture, Universitas Tadulako, 94118 Indonesia $^{2}$
}

\begin{abstract}
The dependence of communities in and around forest areas on natural resources is still very high. The form of interaction is the use of timber and nontimber forest products. This interaction determines and reflects the dependence of the community on the forest. This research aims to determine factors that influence people's interaction patterns in Dongi-Dongi towards the forest and the pattern of their interaction on forest resource management in Dongi-Dongi, Sigi District, Central Sulawesi. The method of the research was conducted by collecting primary data and secondary data. Primary data includes age (X1), an education level (X2), number of family dependents (X3), and income (X4) for 35 respondents and then analyzed using Binary Multiple Regression with SPSS software program to identify factors that influence interaction patterns. Qualitative descriptive was conducted to see patterns of community interaction. The results of data analysis showed that R2 (adjusted R2 squared) obtained a value of 0.843 , meaning that $84.3 \%$ of forest resource management activities were caused by three variables, the t-test on education (0.024), number of dependents (0.007), and income (0.037). Furthermore, the interaction of people in Dongi-Dongi in managing forest resources tends to show a pattern of extraction interaction: the use of forest resources according to their needs, manages wisely and tries to improve and restore its function.
\end{abstract}

Keywords: Interaction, Forest, Dongi-Dongi

\section{Introduction}

Forests play an essential role in the development and have a crucial function in human life. The functions of forests vary, each of which has different factors of importance depending on local situation and conditions. Function mention is the role of forest in maintaining the quality and balance of the environment for humans' benefit.

The ecosystem function of forest resources benefits the people living in the forest area and those who lived outside. Forest ecosystems also play a role in shaping the community's cultural diversity due to human interaction with nature, which enables the emergence of appropriate local technologies, languages, types of food, and arts. Therefore, a healthy forest ecosystem condition will strengthen the supporting capacity for various human life processes around it.

Forest area nowadays are under high pressure from the surrounding community, which cause biophysical damage that leads to the disruption of ecosystem balance of forest in the area. This has led to demands that natural resources be maintained for the continuity of their functions. On the other hand, the interests and roles of the community should not be neglected. 
Because the local community is close to these resources, they must have the right place according to their capacity and portion. Because in reality, natural resources and the community have long-standing relationships and even the indigenous/traditional people.

People who live around the forest highly depend on natural resources. They interact by extracting timber and nontimber forest products, including hunting. The form of interaction between these people and forest areas determines and reflects their dependence on the forests. This occurs in various forest areas, both in production forests, protected forests, and conservation forests.

In general, conservation areas have reached an alarming level of forest land degradation due to forest destruction/encroachment, dry land without any attention to soil conservation principles, and a farming system. This condition illustrates that the forest interaction with the surrounding community as a life support system is not functioning correctly.

In Central Sulawesi Province, especially in Sigi District, the Dongi-Dongi community depends on forest resources. Dongi-Dongi is located in Nokilalaki District, inside the Lore Lindu National Park (TNLL) Central Sulawesi. The existence of TNLL has an essential meaning for the protection of ecosystems and life support systems for the diversity of flora and fauna. Besides, TNLL is also managed with a zoning system and is used for research, science, education, cultivation support, culture, tourism, and recreation purposes. Not only does it play an essential role in the flora and fauna ecosystem, but TNLL is also a source of livelihood for the surrounding community.

The existence of the Dongi-Dongi community in the TNLL area sustains their lives by taking forest products in wood and nontimber and utilizing the land for agriculture/plantations. This situation assumes that the Dongi-Dongi community tends to be seen as encroachment, although this is the community's interaction with forest resources, an adaptation strategy for forest resource management. Therefore, the formulation of the problem in this research are:

1. How is the pattern of interaction between the Dongi-Dongi community towards the management of forest resource

2. Factors influence the interaction pattern of the Dongi-Dongi community towards the management of Forest Resource.

Based on the formulation of the problem, the objectives of this research are:

1. To identify the pattern of interaction between the Dongi-Dongi community on the management of Forest Resource.

2. To identify factors that influence the interaction pattern of the Dongi-Dongi community towards the management of forest resources.

\section{Research Method}

The research was conducted in Nokilalaki Subdistrict, Sigi Regency, Central Sulawesi Province, from August to October 2016. The research location was selected through purposive sampling, considering that the people in that location depend on forest resources. The tools and materials used in this research were writing instruments, cameras, and questionnaires. Thirty-five respondents were taken through purposive sampling, considering their interaction pattern towards the management of forest resources.

Types of data collected include primary data and secondary data. Primary data were obtained through direct observations at the research location and interviews with respondents 
based on a list of questions that had been prepared. Meanwhile, secondary data were obtained through literature related to research.

The data analysis was proceed using the qualitative descriptive analysis to see the patterns of interaction between the Dongi-Dongi communities towards forest resource management. Qualitative research produces descriptive data in written or spoken words from the object of research and observed behavior [1]. It uses and analyzes Binary Regression to see the factors that influence the community towards forest resource management.

$$
Y=60+61 X 1++62 X 2++63 \times 3++64 X 4
$$

Note :

$\mathrm{Y}=$ Community Interaction with Forest Resources

$\mathrm{X} 1=$ Age of Respondents

$\mathrm{X} 2 \quad=$ Education

$\mathrm{X} 3=$ Income

X4 $\quad$ Number of Burden

\section{Result and Discussion}

\subsection{Pattern of People in Dongi-Dongi on the Management of Forest Resource}

Humans and forests have a reciprocal relationship because humans are part of the forest ecosystem. This reciprocal relationship is a form of interplay between humans and forests. This interaction is a form of community socio-economic activities to meet their needs. Dongi-Dongi area located in Nokilalaki District, Sigi Regency, Central Sulawesi Province, is one of the areas within the TNLL area. TNLL itself has 217,9911.18 ha, located in Sigi and Poso districts, where TNLL is in direct contact with 67 villages. Thus it is hoped that DongiDongi will function as a reduction in the rate of forest degradation.

Historically, Dongi-Dongi was a program of resettlement for isolated communities (PKMT) in 1978, in which villagers in Mount Kamalisi - Mount Gawalise (Marawola District) were placed in Palolo District, Donggala Regency (currently in the region. Nokilalaki District, Sigi Regency). In that place, several residents returned to their original area, and many died because of malaria. The government again carried out local transmigration of residents from Salua Village and from the Pipikoro plains, which are of Kulawi ethnicity (Kulawi District) and from Dolo District were placed in Kamarora A Village Kamrora B Village, Kadidia Village, and Rahmat Village. In the PMKT program, the government promised to provide two hectares of land to each head of the family, but what has been realized so far is only 0.8 hectares on average. According to respondents, DongiDongi was still in the working area of the HPH company PT Kebun Sari that produced Agathis trees. After the HPH PT Kebun Sari contract was over, the government held an effort to unite the Lindu Lore Kalimata Forest area with the Lake Lindu Nature Park and become the Lore Lindu National Park (TNLL) area.

The interaction of people in Dongi-Dongi towards the forest was initially the existence of their forest activities by utilizing existing natural resources to survive, and they take fruit and seeds, fish in the river, collect firewood, hunt, and look for rattan. Generally, the community uses the forest to meet consumption needs and sell it to buy other needs.

The interaction can be seen through forest products in the form of wood. People depend on the wood in Dongi-Dongi to fulfill their daily needs; it uses to build as material for houses, which almost entirely uses wood. This is related to [2] that the use of wood is divided into three categories: building material, household utensil material, and fuel. People in Dongi- 
Dongi take/cut trees following their needs, for example, for house building materials. Trees can be cut if they have a diameter of $30 \mathrm{~cm}$. If you cut one tree, then you must replace it by replanting one tree. This is determined based on the agreement of the Dongi-Dongi community, which is regulated in customary rules and if it violates it will be subject to sanctions, this is in line with research [3] that people are generally aware of the need for forests by maintaining, securing and using them as needed.

People do not interact with the nontimber product of the forest due to limited knowledge and skills. Various types of nontimber forest products are found in the Dongi-Dongi area, such as rattan, bamboo, forest honey, palm sugar, medicinal plants, mushrooms, etc. People in Dongi-Dongi take rattan to sell. Some take mushrooms to consume. At the same time, the leaves of Anau are used as the roof of the house. Bamboo trees are used for home furniture (walls), and medicinal plants use them when they are sick.

The form of interaction of people in Dongi-Dongi towards forest resource management is also seen in land use. As time goes by, the generation continues to increase; therefore, limited land will force them to open new land. Land clearing starts from around the place where they live, but they do not cut down trees that produce fruit or seeds, especially when trees are large and continue to grow. The community simply clears the bushes and other lianas and then starts planting perennial crops/plantations and seasonal / crops in their homes' vicinity. People work on their land for 4-5 hours/day. They return home for lunch and rest during the day, but if the land is far, they bring their lunch, so they don't have to go home anymore. The community grows annual crops/plantations such as coffee and cocoa, candlenut, durian, nature, as well as agricultural or seasonal crops such as rice field, corn, cassava, sweet potatoes, vegetables, spices, and so on; this situation is also in line with research [4]; [5]. Annual crops are intended to meet daily needs, and the rest is for sale to fulfill other needs. The community grows local varieties of paddy fields, which are different from those of lowland rice in general. The leaves of cassava plants are used as vegetables, the skin is used for goat food, and some of the fruit (tubers) can be sold. This is in line with research [6]. Whereas cocoa and coffee plants are considered by the community as savings, as in several other studies showing that community interaction with forests tends to be high, marked by the large number of people who fulfill their daily needs from forest areas such as farming, hunting, utilization of nontimber forest products, and others [7]; [8]; [9].

People in Dongi-Dongi manages their land using simple tools such as hoes, sickles machetes, machetes, and others. This is associated with research [10] showing that using simple tools is classified as low-level land use. According to respondents, combining agricultural and forestry crops can provide better benefits from production and costs to land management. The pattern of combining agricultural and forestry crops is supported by the Free Farmers Forum (FPM). This management form is an agroforestry system, namely land use by combining forestry / annual crops with crops. Thus, it can be said that land use by people in Dongi-Dongi goes through three phases, namely, a survival phase, a simply mixed garden phase, and a complex mixed garden phase.

People understand that the land must be carried out wisely and balanced because if it exceeds it, it will harm the environment. Therefore, they keep the environmental balance through mixed gardens (agroforestry system). This pattern is a cropping pattern that can increase land productivity, protect the land from damage, and prevent soil fertility.

The Dongi-Dongi community also carries out plant maintenance both on annual and seasonal crops. For cocoa plants, pruning the branches conducted once every three months and weeding weeds, grass, and other lianas. Whereas in seasonal plants, the maintenance is in the form of cleaning weeds/grass. 
Another form of interaction is crop harvesting activities. Harvesting of plants is carried out on the harvest, both for various types of annual crops such as cocoa, coffee and candlenut, petai, and other crops such as bananas, cassava, sweet potatoes, chilies, tomatoes, vegetables, etc.

However, the orientation and motivation on forest resources' dependence will not be the same between generations due to the negative impacts caused by industrialization and interior modernization. This will cause a degradation of the quality of cultural values. Therefore, assistance and counseling are needed both by the government and other non-governmental organizations [11].

People in Dongi-Dongi carry out forest pedestrian efforts through rehabilitation and conservation efforts and utilize the forest and land. The community depends on their livelihoods from natural resources, which are not only on forest production (timber and nontimber) and forest land and on the protection and climatic functions. Therefore, they try always to protect the forest so that the protection and climatic systems continue to function. Rehabilitation efforts were held out through replanting trees. The community also undertook conservation efforts by planting bamboo along the riverbanks. People in Dongi-Dongi see the forest as a source of food, medicine, energy, and clothing and strives to protect the environment because it is their residence and, at the same time, for the continuation of their generation.

The current land use pattern illustrates that people in Dongi-Dongi still cares about the ecological side of the lan. They protect the forest and feel responsible for preserving it. This is in line with the research results of [12]; [13]; [14] stated that people conserving forest areas tend to be high because they realize and understand how vital forest conservation is. Local communities' lives depend on existing resources, so that they need to be managed sustainably through actions or activities to keep the natural resources in the forest from becoming extinct. Forest sustainability and the economic life of people in Dongi-Dongi are two things that influence each other.

The dependence of people in Dongi-Dongi towards the forest, to a certain extent, can be seen through the benefits from the resource, namely the preservation of its structure and function. The existence of interdependence between communities and forest resources in line with research [15] states that the longer a person lives and stays in an area, it will have a positive influence so that there is awareness to maintain and to manage the area.

[16] there are four patterns of forest-community interaction, namely: a. Extraction patterns, the use of resources to the limit of necessity controlled by prevailing ethics and norms, use of forest resources wisely and carefully; b. The pattern of exploitation, the consequence of an increase in population and an increase in the necessities of life, causes the social system to separate from the forest system; c. Confrontation pattern, the existence of a high conflict of interest resulting in the absence of clarity regarding the alignment of economic development interests and the need to conserve the functions and benefits of forest resources required by local communities; and $\mathrm{D}$. Cooperative pattern, the existence of similar interests between efforts to improve community welfare (social system) and maintain the sustainability of the structure and function of forest resources.

Based on the description above, the activities of people in Dongi-Dongi towards forest resource management tend to show a pattern of extraction interactions. According to their needs, the community uses forest resources, manages them wisely, and tries to improve restore its functions. 


\subsection{Factors Affecting the Interaction Pattern of People in Dongi-Dongi on the Management of Forest Resource}

Efforts to determine factors that influence respondents' propensity to engage in forest resource activities can be done through analyzing several variables, namely age (X1), an education level (X2), number of family burden(X3), and respondent income (X4).

Data analysis shows that R2 (adjusted R2 squared) has a value of 0.843 , meaning that three influencing variables cause $84.3 \%$ of the tendency of forest resource management activities. The results of the t-test are shown in the following table.

Table 1. Significance level of each variable on the tendency to manage forest

\begin{tabular}{llc}
\hline No & \multicolumn{1}{c}{ Variable } & Significance \\
\hline 1 & Age(X1) & 0,17 \\
2 & Education (X2) & 0,024 \\
3 & Family Burden (X3) & 0,007 \\
4 & Income (X4) & 0,037 \\
\hline
\end{tabular}

Table 1 shows the results of the regression analysis that of the four (4) variables, there are three (3) variables that affect the activities of people in the Dongi-Dongi on forest management, namely education (X2), number of family dependents (X3) and total income (X4)., where the t-test on education (0.024), number of family burden (0.007), and income (0.037). The age variable statistic has several more than 0.5 , which means that the age variable is not significant or affects community activities on forest resource management.

1). Age (X1)

Age affects the ability and works performance both physically and mentally as well as in making a decision. In general, younger respondents will have relatively well physical abilities and are dynamic in applying new technology. In comparison, older respondents have low physical abilities and rely more on experience to act carefully.

Table 2. Respondents Age State

\begin{tabular}{lllcc}
\hline No & $\begin{array}{c}\text { Age } \\
(\text { Old })\end{array}$ & $\begin{array}{c}\text { Total Respondent } \\
(\text { Person) }\end{array}$ & $\begin{array}{c}\text { Presentation } \\
(\boldsymbol{\%})\end{array}$ \\
\hline 1 & $\leq 20$ & 3 & 8,57 \\
2 & $21-54$ & 31 & 88,57 \\
3 & $\geq 55$ & 1 & 2,86 \\
\hline & Total & 35 & 100 \\
\hline
\end{tabular}

Table 2 shows 31 respondents are aged 21-54 years old. The t-test results in Table 1 for the age variable show the number of 0.17 , meaning that the age variable does not significantly affect forest resource management. This contrasts with the research results [17] that this age is included in the productive age category, which shows physical potential at work. 
2). Education (X2)

The level of education is a formal activity that the respondent has gone through in his life. The formal activity referred to is education, starting from the elementary school level to the next level.

Table 3. State of Respondents Education Level

\begin{tabular}{llcc}
\hline No & Education Level & $\begin{array}{c}\text { Total Respondent } \\
\text { (person) }\end{array}$ & $\begin{array}{c}\text { Presentation } \\
(\boldsymbol{\%})\end{array}$ \\
\hline 1 & Elementary School & 21 & 60 \\
2 & Junior High School & 9 & 25,72 \\
3 & Senior High School & 2 & 5,71 \\
4 & No School & 3 & 8,57 \\
\hline & Total & 35 & 100 \\
\hline
\end{tabular}

Table 3 shows that 21 respondents $(60 \%)$ are in the elementary school education level (SD). The t-test result shows the number 0.024 , which means that the level of education has a significant effect on community activities toward forest resources management. Most of the time in his life (respondent), he spent managing his fields and gardens because he does not have other jobs. His life depends entirely on the gardens and fields. The low level of education causes low processing of forest and agricultural products. Generally, people sell their product directly without processing it to reach a higher value. [18] said a person's education could affect creativity in service and increase performance in their work. The increased number of people and limited land can encourage someone to carry out activities in the forest. This is related to the urge to fulfill their daily needs. Also, the low level of education has an impact on business opportunities in other sectors.

3). Number of Burden (X3)

The number of burdens of the respondent's family is measured by the number of family members who depend on the respondent, both for residence and daily living expenses.

Table 4. State of the Number of Family Burden of the Respondents

\begin{tabular}{llcc}
\hline \multicolumn{5}{c}{ No } & $\begin{array}{c}\text { Burden } \\
\text { (person) }\end{array}$ & $\begin{array}{c}\text { Total } \\
\text { Respondent } \\
\text { (Person) }\end{array}$ & $\begin{array}{c}\text { Presentation } \\
(\boldsymbol{\%})\end{array}$ \\
\hline 1 & $1-2$ & 16 & 45,71 \\
2 & $3-4$ & 17 & 48,57 \\
3 & $\geq 5$ & 2 & 5,72 \\
\hline & Total & 35 & 100 \\
\hline
\end{tabular}

Table 4 above shows that 17 respondents (48.57\%) own a $3-4$ burden. The result of the t-test shows a significant level of 0.007 , which means that the number of family burden has a significant effect on community activities in the management of forest resource [19] stated that the higher the number of family burden, the more the need will increase and encourage farmers to invite family members to use the forest. 


\section{4). Income (X4)}

Respondents' income levels are obtained from cocoa, candlenut, and vegetables, as shown in the following table.

Table 5. State of Respondents Income Level

\begin{tabular}{|c|c|c|c|}
\hline No & $\begin{array}{l}\text { Income } \\
\text { (Rp/Year) }\end{array}$ & $\begin{array}{c}\text { Total Respondent } \\
\text { (Person) }\end{array}$ & $\begin{array}{c}\text { Presentation } \\
(\%)\end{array}$ \\
\hline 1 & $<5.000 .000$ & 4 & 11,42 \\
\hline 2 & $5.000 .000-8.000 .000$ & 23 & 65,71 \\
\hline \multirow[t]{2}{*}{3} & $>8.000 .000$ & 8 & 22,85 \\
\hline & Total & 35 & 100 \\
\hline
\end{tabular}

Table 5 shows that 23 respondents had an income level of Rp. 5,000,000, - - Rp. $8,000,000,-/$ year. The t-test result shows a significant level of 0.037 , which means that the amount of income level affects community activities in forest resources management. The respondents' low income in the research location was because the community cultivated area was only $0.5-1$ ha. Besides, respondents did not have the skills to process forest and agricultural products. The land area affects the amount of income. This is in line with research [20] that the increased land area will increase community income. The community clears the forest to increase the area they cultivate, intending to plant crops, and they think that this can help them meet their needs.

\section{Conclussion}

The interaction pattern of people in Dongi-Dongi in managing forest resources shows a pattern of extraction interaction. The use of forest resources is following the needs. They manage it wisely and tries to improve and restore their function.

The results of data analysis show that R2 (adjusted R2 squared) has a value of 0.843 , meaning that $84.3 \%$ of the tendency of forest resource management activities is caused by three influential variables, namely the level of education $(0.024)$, the number of family burden (0.007), and income (0.037).

\section{References}

[1]. Moleong LJ. Metodologi Penelitian Kualitatif (XXVII). Bandung: Remaja Rosdakarya. 2010;

[2]. Nurrani L, Tabba S. Persepsi dan tingkat ketergantungan masyarakat terhadap sumberdaya alam Taman Nasional Aketajawe Lolobata di Provinsi Maluku Utara. J Penelit Sos dan Ekon Kehutan. 2013;10(1):61-73.

[3]. Pusat Penelitian dan Pengembangan Perubahan Iklim dan Kebijakan Jl Gunung Batu No S. ANALISIS SIKAP DAN PERILAKU MASYARAKAT TERHADAP HUTAN PENELITIAN PARUNG PANJANG ( ) Attitude and Behavior Analysis of Communities Toward Parung Panjang Research Forest. 2014;339-47.

[4]. Kutai TN. 1) 1) 1). 2011;(325):129-42.

[5]. Maiwa A, Umar S, Rahman A, Kehuutanan J, Kehutanan F, Tadulako U. Resolusi konflik dalam pengelolaan taman nasional lore lindu. 2018;6(2011):47-54.

[6]. Kristin Y, Qurniati R, Kaskoyo H. Interaksi masyarakat sekitar hutan terhadap pemanfaatan 
lahan taman hutan raya wan abdul rachman. J Sylva Lestari. 2018;6(3):1-8.

[7]. Subarna T. Faktor yang mempengaruhi masyarakat menggarap lahan di hutan lindung: studi kasus di Kabupaten Garut Jawa Barat. J Penelit Sos dan Ekon Kehutan. 2011;8(4):265-75.

[8]. Sumanto SE, Takandjandji M. Identifikasi pemanfaatan hasil hutan oleh masyarakat: Upaya konservasi sumber daya genetik dan sosial budaya. Bul Plasma Nutfah. 2016;20(1):27-40.

[9]. Neil A, Golar, Hamzari. Hutan bukan kayu pada taman nasional Lore Lindu ( Studi Kasus Desa Sidondo I Kecamatan Biromaru dan Desa Pakuli Kecamatan Gumbasa ). e-Jurnal Mitra Sains. 2016;4(1):29-39.

[10]. Lewerissa E. Interaksi Masyarakat Sekitar Hutan terhadap Pemanfaatan Sumberdaya Hutan di Desa Wangongira, Kecamatan Tobelo Barat. J Agroforestri. 2015;X(1):10-20.

[11]. Reski NA, Yusran Y, Makkarennu M. Rancangan Pemberdayaan Masyarakat pada Pengelolaan Hutan Kemasyarakatan (HKm) Desa Pacekke, Kecamatan Soppeng Riaja, Kabupaten Barru, Sulawesi Selatan. J Hutan dan Masy. 2017;9(1):37-43.

[12]. Damayatanti PT. Upaya Pelestarian Hutan Melalui Pengelolaan Sumberdaya Hutan Bersama Masyarakat. Komunitas Int J Indones Soc Cult. 2013;3(1):70-82.

[13]. Lestari T, Agussabti A, Alibasyah MR. Partisipasi Masyarakat Adat dalam Konservasi Sumberdaya Hutan di Kecamatan Kota Jantho Kabupaten Aceh Besar. J Manaj Sumberd Lahan. 2014;3(2):506-16.

[14]. Damiati V, Lumangkun A, Dirhamsyah M. Partisipasi masyarakat dalam melestarikan kawasan hutan lindung gunung buduk sebagai sumber air bersih di Desa Idas Kecamatan Noyan Kabupaten Sanggau. J Hutan lestari. 2015;3(1):142-9.

[15]. Wijaksono S. Pengaruh lama tinggal terhadap tingkat partisipasi masyarakat dalam pengelolaan lingkungan permukiman. ComTech Comput Math Eng Appl. 2013;4(1):24-32.

[16]. Sardjono MA. Mosaik sosiologis kehutanan: masyarakat lokal, politik dan kelestarian sumberdaya. Fakultas Kehutanan dan Center for Social Forestry (CSF), Universitas ...; 2004.

[17]. Achmad B, Diniyati D, Fauziyah E, W TS. ANALISIS FAKTOR-FAKTOR PENENTU DALAM PENINGKATAN KONDISI An analysis of key factors in improving the social economic condition of private forest in Ciamis District. J Hutan Tanam. 2015;11(3):63-79.

[18]. Sujana LR. Pengaruh Tingkat Pendidikan dan Kreatifitas Pegawai terhadap Kualitas Pelayanan pada Kantor Kecamatan Sangkulirang Kabupaten Kutai Timur. J Pemerintah Integr. 2017;5(1):1-15.

[19]. Mamuko F, Walangitan H, Tilaar W. Persepsi dan partisipasi masyarakat dalam upaya rehabilitasi hutan dan lahan di Kabupaten Bolaang Mongondow Timur. Eugenia. 2016;22(2).

[20]. Sukardi S. Analisis Pendapatan Masyarakat Desa untuk Kelestarian Hutan Lindung (Studi Hutan Desa Pattaneteang Kabupaten Bantaeng). J Hutan dan Masy. 2017;9(1):44-53. 